\title{
Сучасний підхід до лікування інсульту. Національні рекомендації
}

Згідно з даними звіту «Тягар інсульту в Європі» («Burden of Stroke in Europe»), в період 2015-2035 рр. прогностичне підвищення частоти інсульту становитиме $34 \%$ внаслідок старіння населення, а абсолютна кількість населення країн Європи, які перенесли інсульт, сягне 4631050 осіб. До 50\% хворих на інсульт помирає впродовж 1-го року після події, з них 40\% - у 1-й місяць. 40\% пацієнтів, що вижили, стають залежними від сторонньої допомоги, і лише 10\% повертаються до повноцінного життя. Актуальність проблеми гострого інсульту в Україні зумовлена високим рівнем смертності внаслідок порушення мозкового кровообігу. У структурі смертності інсульт посідає 2-ге місце і залишається провідним чинником смерті у 14\% пацієнтів. Проблематика інсульту полягає у вчасному наданні медичної допомоги у перші 4 год після інсульту з подальшим лікуванням залежно від клінічних характеристик пацієнта. Ключовими аспектами допомоги при спонтанному нетравматичному мозковому крововиливі наразі вбачається надання медичної допомоги в гострий період, кваліфікований сестринський догляд та реабілітація після інсульту. Незважаючи на значний рівень інформатизації, в Україні не вистачає достовірної інформації про структуру та організацію медичної допомоги при інсульті. До сих пір не створена система сертифікації з чітко визначеними критеріями ефективності медичної допомоги. Не впроваджена система моніторингу з метою порівняльного аналізу показників ефективності надання допомоги. Суперечливим і складним залишається питання реабілітаційних програм при інсульті, які часто базуються на застарілих та неоднорідних даних. Ці та інші гострі питання спричинили пошук оптимального клінічного рішення, яке повинно відображатися в національному стандарті лікування спонтанного нетравматичного мозкового кровообігу. Національні стандарти надання медичної допомоги при інсульті скеровані на впровадження планів організації допомоги, які охоплюють весь ланцюг надання допомоги, грунтуються на доказах, адаптовані до локальних умов та зрозумілі лікарям та населенню. Отримання адекватного лікування у перші години після інсульту має велике значення для відновлення пацієнта. Зважаючи на принципове значення реабілітаційних програм, можна стверджувати, що належна реабілітаційна практика повинна складатися з ранньої профілактики, яка проводиться у лікарні, та позалікарняної профілактики. Рання профілактика спрямована на зменшення неврологічного дефіциту та пришвидшення віднов-

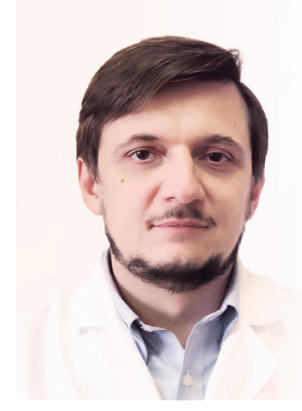
лення пацієнта. Аби попередити та зменшити наслідки катастрофи прогнозованого зростання частоти інсультів в країні, необхідно докласти спільних зусиль на кожному етапі надання медичної допомоги при інсульті. Для тривалої реабілітації в національних настановах повинно бути акцентовано на організацію позалікарняної підтримки пацієнтів, які пережили інсульт. Як ефективно лікувати інсульт? Які показники ефективності лікування інсульту? Де знайти інформацію щодо оптимальної стратегії лікування пацієнтів із гострим інсультом? Як лікарю обрати настанову або рекомендацію, зважаючи на їх чисельність? Чи може окрема лікарня затвердити власні рекомендації? Чи $\epsilon$ підстави для застосування ранньої фармакологічної реабілітації при гострому інсульті? А як лікують пацієнтів із гострим порушенням мозкового кровообігу європейські колеги? Про стан готовності національних рекомендацій щодо ведення пацієнтів із гострим порушенням мозкового кровообігу розповідає Дмитро Лебединець, кандидат медичних наук, лікар-невролог вищої категорії, керівник Інсультного центру Клінічної лікарні «Феофанія» Державного управління справами.

- Дмитре Володимировичу, як лікарі, так і спільнота пацієнтів, із нетерпінням очікують на оновлені національні настанови щодо лікування інсульту, що зрозуміло: питання гостре, враховуючи поширеність та негативні соціальні наслідки гострого інсульту. Які переваги оновлених рекомендацій?

- Почну з того, що інсульт - це не одне захворювання, а інтегральний клінічний стан, в якому виділяють кілька взаємопов'язаних, проте незалежних клінічних синдромів. Існують три підгрупи рекомендацій: рекомендації щодо лікування гострої фази порушення мозкового кровообігу, реабілітаційне лікування та рекомендації щодо профілактики інсульту. Коли мова йде про оновлення національних настанов, мається на увазі внесення в узагальнені клінічні настанови того нового, що з'явилося у сфері лікування інсульту за останній час.

- Тобто рекомендації базуються на отриманих результатах дослідження та набутому практичному досвіді, на підставі якого й

формуються діагностично-лікувальні алгоритми.

А за який час оновлюються рекомендації?

- Тут має значення, про рекомендації якої організації чи країни йде мова. Залежно від тематики це можуть бути й вперше видані настанови, в яких акцентовано увагу на підходах до лікування, які до того не застосовували. Сталі рекомендації оновлюються впродовж періоду 3-7 років залежно від видавця. Однак якщо вдається виявити фактор, який принципово впливає на діагностично-лікувальний алгоритм, то зміни до ре- комендацій узгоджують швидко, й оновлення виходить навіть за рік.

- На попередньому брифінгу Національної служби здоров'я України щодо питання методологічного

підходу до лікування гострого інсульту йшла мова про вихід стандарту медичної допомоги в 2022 р. На основі яких рекомендацій формується національний стандарт?

- Міжнародні рекомендації видають визнані у світі професійні організації, такі як Європейський альянс боротьби з інсультом (SAFE), Європейська організація інсульту (ESO), Європейська академія неврології (EAN), Канадський фонд серця та інсульту (HSF), Американська асоціація серця та Американська асоціація інсульту (AHA/ASA). В Україні існує пул медико-нормативних документів, які відображають роботу експертної групи фахівців. До таких документів належать стандарт медичної допомоги, уніфікований клінічний протокол медичної допомоги та сама клінічна настанова.

- Дуже важливим аспектом в лікуванні інсульту $\epsilon$

рання реабілітація, яка починається вже с перших днів після інсульту. Чи включені до Європейських рекомендацій фармакологічні засоби, які можуть підсилити ефект ранньої реабілітації?

- Реабілітація залишкових симптомів гострого інсульту залишається актуальним питанням в усіх країнах. На заваді інвалідизації пацієнтів після інсульту може стати рання реабілітація шляхом застосування адекватної фармакологічної підтримки. В останніх рекомендаціях Європейської академії неврології 3 
фармакологічної підтримки ранньої реабілітації пацієнтів після інсульту, які опубліковані в червні 2021 р., рекомендується застосування препарату Церебролізин ${ }^{\circledast}$ та циталопраму в супратерапевтичній дозі в перші 7 днів після інсульту. Більше того, концепція підсилення ефекту ранньої моторної реабілітації шляхом застосування препарату Церебролізин ${ }^{\circledR}$ підтверджена і він рекомендований цілим рядом авторитетних професійних організацій референтних для України західних країн. Відповідно до рекомендацій Австрійської асоціації боротьби з інсультом (ASS) 2018 р. Церебролізин ${ }^{\circledast}$ рекомендований для покращення відновлення моторної функції верхніх кінцівок. Парез верхніх кінцівок - найбільш поширене ускладнення інсульту, яке обмежує працездатність і погіршує якість життя пацієнтів. Згідно з настановою Німецького товариства нейрореабілітації (DGNR) 2020 р. призначення препарату Церебролізин ${ }^{\oplus}$ рекомендовано в перші 24-72 год після інсульту. За умови задовільної переносимості його застосування можна продовжити протягом 21 дня. Таких самих настанов дотримується Швейцарське товариство з реабілітації. У Канадських рекомендаціях також доведено ефективність методів реабілітації. Церебролізин ${ }^{\oplus}$ визнано засобом, який покращує моторну функцію верхніх кінцівок (рівень доказовості 1А), полегшує клінічні симптоми інсульту і покращує якість життя (рівень доказовості 1В). Високу ефективність цього препарату визнано і польськими фахівцями включенням його до національних рекомендацій 3 лікування спонтанного нетравматичного порушення мозкового кровообігу ішемічного генезу. На стадії ранньої реабілітації Церебролізин ${ }^{\oplus}$ зарекомендував себе як препарат з найвищою ефективністю серед цілого ряду лікарських засобів. При його застосуванні покращується неврологічний стан пацієнтів, зменшується спастичність, покращуються функціональні можливості паретичних кінцівок.

\section{- На базі яких установ формується експертна група, яка} видає в Україні національні рекомендації? На якому етапі знаходиться розробка національного стандарту?

- При створенні національного стандарту за основу взято настанову однієї з вищезгаданих авторитетних міжнародних фахових організацій. Для розробки та оновлення національних рекомендацій створюється робоча група з фахівців, дотичних до проблеми інсульту, фахівців Державного експертного центру, МО3 та Національної служби здоров'я України. Експертна група розробляє водночас декілька напрямків, пов'язаних з інсультом. Передусім це лікування спонтанного нетравматичного мозкового крововиливу. По-друге, вже опрацьована настанова з тромболітичного лікування у пацієнтів із гострим ішемічним інсультом. По-третє, заплановано роботу над національним стандартом виконання механічної тромбектомії у пацієнтів із ішемічним інсультом - найсучаснішого методу лікування гострого порушення мозкового кровообігу внаслідок ішемії. Наразі робота експертів добігає фінальної стадії, і ми в очікуванні оприлюднення проєкту національного стандарту для громадського обговорення.

- Тобто складовими національного стандарту

лікування гострого інсульту реально $\epsilon$ три

настанови: $з$ лікування гострого інсульту,

проведення тромболізису та виконання

тромбектомії. 3 чим пов'язаний окремий

методологічний підхід до цих методів лікування?

- Окремий методологічний підхід зумовлений специфічністю та відсутністю практики застосування методів при інших нозологіях. Стандарт прописує можливі умови застосування цих методів лікування, які залежать передусім від ресурсів лікувального закладу та навичок персоналу. До того ж частота виконання цих процедур $є$ математичним коефіцієнтом, який визначає ефективність лікування гострого інсульту.

- Враховуючи клінічну актуальність проблеми

інсульту, які терміни передбачені для

затвердження національних стандартів?

- Сподіваємося, що стандарти з лікування спонтанного нетравматичного мозкового крововиливу, тромболізису та тромб- ектомії будуть прийняті на початку 2022 р. Вже цього року планується громадське обговорення стандарту, після чого впродовж 1,5-2 міс роботу буде завершено. Наступним етапом планується загальний стандарт з ведення пацієнтів із ішемічним інсультом у найгостріший та гострий періоди. Далі плануємо переходити до розробки питань реабілітації. У перспективі, враховуючи обов'язковість дотримання стандарту лікування, розраховуємо отримати статистичні дані, які будуть спрямовувати подальший розвиток надання медичної допомоги.

\section{- Як реалізується на практиці громадське обговорення?}

- На сайті МОЗ є розділ, куди подають проєкти наказів, i, звісно, стандарт надання медичної допомоги при інсульті буде прийнятий наказом МОЗ після попереднього розміщення на сайті з метою обговорення. Взяти участь в обговоренні, подати свої пропозиції та зауваження може будь-яка особа, яка $\epsilon$ фахівцем у цій сфері. Усі зауваження будуть розглянуті фахівцями експертної групи, на фінальному етапі рішення буде оприлюднено на цьому ж сайті. На заключному етапі інформація про узгоджені національні стандарти поширюється через фахові організації. Зокрема Українське товариство інсультної медицини буде поширювати інформацію через свій сайт та сторінку в Фейсбуці.

- Велика кількість рекомендацій та настанов на практиці часто призводить до упередженості розуміння алгоритму та ускладнює прийняття оптимального клінічного рішення. Оскільки національний стандарт лікування інсульту ще не затверджений, чи обов'язково лікарю дотримуватися міжнародних рекомендацій? На що звертати увагу практичному лікарю при виборі рекомендації?

- Це важливе питання, i, дійсно, воно нас всіх бентежить. Звіт «Тягар інсульту в Європі» 2017 р. виявив шокуючі розбіжності в національних підходах до лікування гострого інсульту та нехтування післяінсультною реабілітацією в усіх країнах, і Україна - не виняток. Справа в тому, що до 2016 р. «наші» $\mathrm{i}$ «чжжі» уніфіковані клінічні протоколи традиційно містили лікарські засоби з недоведеною ефективністю. Зміни в наказі МОЗ України від 28.09.2012 р. № 751 дозволили кожній лікарні проявити ініціативу і впровадити в практику ту настанову країн Європейського Союзу, Канади, Австралії та США, для застосування якої у лікарні $\epsilon$ ресурс. Крім того, можна спиратися на Кокрейнівські огляди, авторитетні джерела доказової медицини (наприклад UpToDate), «British Medical Journal». Після перекладу обраної настанови українською видається відповідний наказ по закладу про використання цієї настанови у якості клінічного протоколу. Наказ № 751 це якраз і дозволяє. Особливість полягає у додатковій угоді до стандартної форми на використання нового клінічного протоколу, яку підписують як лікар, так і паці$\epsilon \mathrm{HT}$.

\section{- Хотілося 6 почути вашу думку щодо} особливостей європейських настанов.

- Незважаючи на існування національних настанов в кожній окремій країні, в країнах Європи поширені також уніфіковані настанови від ESO та EAN - двох великих організацій, які опікуються в тому числі проблемою інсульту. Вихід настанов під егідою цих організацій $є$ сигналом для європейських країн провести ревізію своїх національних стандартів. Наприклад, лікар з Німеччини замість національного стандарту лікує пацієнта відповідно до настанови ESO, і це не створює проблеми, тому що вона видана фаховими організаціями експертного рівня.

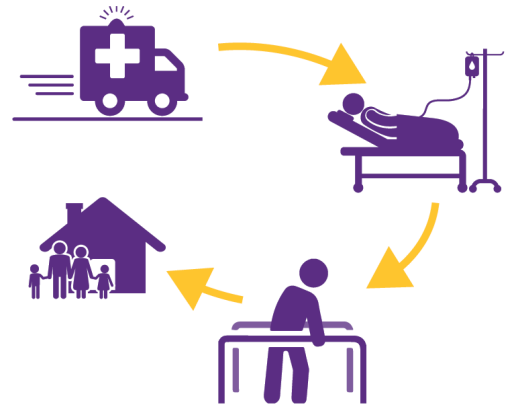


-А від чого залежать розбіжності національних стандартів?

- Особливості національного стандарту передусім залежать від розміру популяції та ландшафтних особливостей конкретної країни. Звісно, географічні особливості неабияк впливають на розвиток інфраструктури та доступність медичної допомоги. Наприклад, в Швейцарії розвинено авіасполучення завдяки гірському ландшафту. У кожній країні свої інфраструктурні нюанси, які необхідно враховувати. Крім того, має значення доступність ліків, частина з яких може мати реєстрацію в одній країні і не мати в іншій. Наприклад для лікування синдрому гіпертермії у пацієнтів з інсультом в більшості країн Європи застосовують парацетамол, за винятком Німеччини.

-У Німеччині застосовують нестероїдні протизапальні препарати?

- Hi, при симптоматичній терапії гіпертермії у пацієнтів із гострим інсультом перевагу надають застосуванню препаратів з вмістом метамізолу натрію, що пов'язано з розташуванням виробництва цієї групи препаратів на території Німеччини. Або, наприклад, для лікування підвищеного артеріального тиску у пацієнтів із інсультом стандартом у більшості європейських країн $\epsilon$ урапідил, а у США, Великобританії, Японії найпоширенішим $\epsilon$ лабеталол. Тому коли йде мова про міжнародні клінічні стандарти, найкраще адаптувати їх під місцеві умови певної країни.

- Як фахівець з експертним досвідом у сфері

лікування інсульту, прокоментуйте, будь ласка, які клінічні протоколи найпоширеніші в Україні?

- У нас найчастіше користуються клінічними настановами AHA/ASA. Говорячи про інсульт, доречно згадати Канадський фонд серця та інсульту, настанови ESO, EAN, британські настанови NICE. До цього основного пулу настанов я 6 додав ще Австралійські настанови, які менш поширені, але викликають цікавість завдяки оновленню щопівроку, так звані живі настанови. Їх особливість полягає в датуванні внесених змін, що надає можливість відстежити виникнення нових методів лікування, оскільки все нове оперативно вноситься в настанову.

\section{- Як регулюються юридичні аспекти застосування}

клінічних настанов в Україні, враховуючи їх

чисельність? Які механізми регуляції існують?

- Я не юрист, а лікар. Але наказ МО3 України № 751, який дозволяє дотримуватися інших клінічних протоколів, $\epsilon$ юстованим. Один із постулатів цього наказу звучить так: якщо ви користуєтеся новим клінічним протоколом, ви можете не користуватися уніфікованою настановою. Справа в тому, що уніфіковані настанови з лікування ішемічного інсульту від 2012 р. та геморагічного інсульту від 2012 р. вже застаріли. Таким чином, держава надала можливість використовувати так звані нові клінічні протоколи. Тобто якщо лікарня в особі головного лікаря впроваджує новий клінічний протокол, вона має всі юридичні права відмовитися від морально застарілої уніфікованої настанови. Але якщо з'явиться національний стандарт, то він буде мати перевагу і стане обов'язковим для всіх лікарень, тому що стандарт передбачає найвищий рівень надання медичної допомоги.

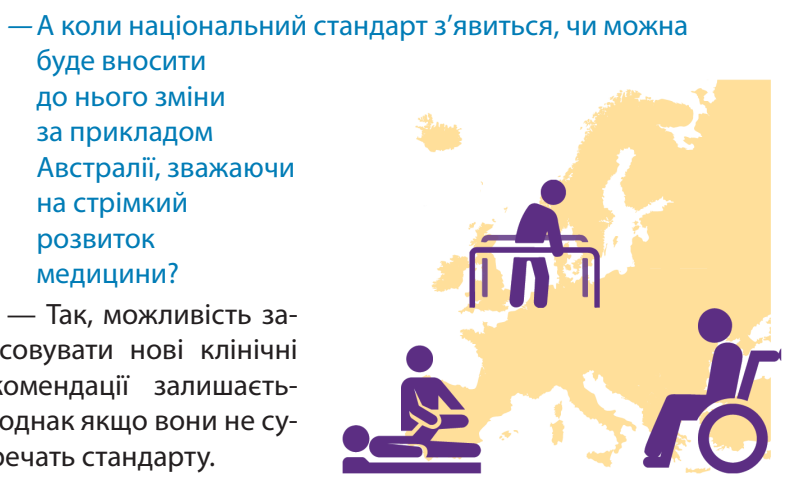

- А коли національний стандарт з'явиться, чи можна

буде вносити

до нього зміни

Австралії, зважаючи

на стрімкий

розвиток

медицини?

Так, можливість зарекомендації залишається, однак якщо вони не суперечать стандарту.
- Скажіть, будь ласка, як контролюється якість надання медичної допомоги пацієнтам із інсультом?

- На превеликий жаль, статистичний збір даних в Україні обмежений. Коли говоримо про інсульт, то статистичні дані репрезентують лише чисельність госпіталізованих із діагнозом «інсульт» та кількість померлих внаслідок гострого порушення мозкового кровообігу в лікарнях. Ми не знаємо частоту залишкових явищ після інсульту, скільки людей отримують інвалідність, не знаємо річну летальність, частоту повторних інсультів.

- Невже ми нічого цього не знаємо?

- На жаль, саме так. Наразі функціонує реєстр Res-Q, але він охоплює лише гострий період, тобто лише тих пацієнтів, яких було госпіталізовано. Аби вплинути на ситуацію, в Дніпрі та Полтаві впроваджено пілотний проєкт із створення єдиного реєстру інсульту, куди долучають всіх пацієнтів із інсультом з метою відслідковування наслідків інсульту впродовж хоча 63 міс. Бо ефективність лікування дуже важко відслідкувати. Часто госпітальна летальність $€$ сурогатним показником, бо пацієнтів можуть передчасно переводити на амбулаторний режим, щоб не псувати показники лікарні. Таким чином лікарня не має проблем з летальністю, а пацієнт помирає вдома. Тому важливо відслідковувати клінічний стан пацієнта хоча 6 протягом перших 3 міс - найкритичніший період розпалу ранніх та виникнення пізніх ускладнень.

- Як на практиці буде відслідковуватися стан пацієнта?

Чи буде створено катамнестичні кабінети?

- Так, йде мова про створення катамнестичного центру на базі лікарні Мєчнікова у м. Дніпро, лікарні Скліфосовського в Полтаві та невеликих лікарень поблизу. Пілотний проєкт передбачає, що навчені працівники шляхом застосування телефонії відслідковують катамнез пацієнта впродовж 3 міс після виписки з лікарні.

- Нагальне питання: чи планує Українське товариство інсультної медицини проводити навчання лікарів?

- Ми вже проводимо тренінги з першої допомоги при інсульті, які спрямовані на надання медичної допомоги під час госпіталізації пацієнта до прийняття клінічного рішення $з$ метою зниження смертності. Тренінг передбачає навчання застосовувати шкальний метод для оцінювання стану пацієнта. За умови затвердження національного стандарту метод оцінювання за шкалами буде включений в обов'язкову програму тренінгів для фахівців. Акцентую увагу також на інформаційній підтримці та доведенні до відома лікарів інформації щодо змін або оновлень настанов авторитетних видавців. Зокрема цього року EAN вперше видала настанову щодо моторної реабілітації пацієнтів із залишковими наслідками ішемічного інсульту, вперше розглянуто фармакологічну моторну реабілітацію. Зазвичай основна робота з реабілітації проводиться фізіотерапевтом та ерготерапевтом. Але на тлі фармакопідтримки можна пришвидшити відновлення пацієнта, покращити якість його життя та зменшити економічні втрати. Як було зазначено вище, результати аналізу цілого пулу препаратів свідчать, що лише два з них мають рекомендаційний характер - циталопрам в дозі 20 мг та Церебролізин ${ }^{\circledR} 30$ мл/добу внутрішньовенно мінімум 10 діб. Перевагою препарату Церебролізин ${ }^{\circledast} \epsilon$ його швидка нейротрофічна активність, яка проявляється вже в перші 24 год після початку лікування. Застосування препарату в ранній реабілітаційний період полегшує функціональне відновлення, що зменшує залежність пацієнта від сторонньої допомоги, знижує вартість лікування, поліпшує настрій і покращує якість життя пацієнта та навколишнього оточення.

- Дякую вам, Дмитре Володимировичу, за приділену увагу та змістовне інтерв'ю, в якому ми говорили про такі складні, але надважливі речі.

Бесіду вела Юлія Жарікова, фото люб'язно надано Д.В. Лебединцем

Ілюстрації запозичені з: European Stroke Organisation (2018) План дій боротьби з інсультом у Євpоnі на 2018-2030 pp. (https://www.safestroke.eu/wp-content/uploads/2019/05/sapukraine-s.pdf). 